\title{
Генетические ресурсы - первооснова результативной селекции яровой пшеницы в Беларуси
}

Гриб С.И., д.с.-х.н., г.н.с.; Маркевич И.М., н.с.; Матыс И.С., к.с.-х.н., зав. отделом генетических ресурсов растений; Буштевич В.Н., к.с.-х.н., зав. лабораторией тритикале; Шабан Е.М., м.н.с.

РУП «Научно-практический центр НАН Беларуси по земледелию», г. Жодино, Республика Беларусь.

e-mail: belgenbank@mail.ru

В статье представлены результаты изучения и использования генофонда в селекиии мягкой яровой пшеницы (Triticum L.). Выявлены генетические источники хозяйственно иенных признаков. Показаны результаты селекичи в Беларуси.

Ключевые слова: генетические ресурсы растений, пшеница мягкая яровая, генбанк, коллекция.

\section{Genetic resources - primary basis for effective spring wheat breeding in Belarus}

Grib S.I., Markevich I.M., Matys I.S., Bushtevich V.N., Shaban E.M., Research and Practical Center of the NAS for Arable Farming, Zhodino, the Republic of Belarus,

*e-mail:belgenbank@mail.ru

The paper presents the results of study and use of gene pool in spring wheat breeding (Triticum L.). Genetic sources of economically important traits are identified. The results of plant breeding in Belarus are stated.

Key words: plant genetic resources, spring wheat, genebank, collection.

Мировые генетические ресурсы растений являются исходным материалом - основой для создания новых высокоурожайных и высокотехнологичных конкурентоспособных сортов $[1,2]$.

С 2000 года в Беларуси в рамках ГП «Генофонд растений» проводится научно-исследовательская работа в области мобилизации, изучения, сохранения и использования генетических ресурсов растений, создан Национальный банк семян генетических ресурсов хозяйственно полезных растений РУП «Научно-практический центр НАН Беларуси по земледелию», Республика Беларусь стала членом ECPGR и AEGIS, налажен обмен генофондом с зарубежными генными банками и международными научными центрами.

Среди коллекций Национального банка семян генетических ресурсов хозяйственно полезных растений РУП « Научно-практический центр НАН 
Беларуси по земледелию» коллекция пшеницы (Triticum L.) самая многочисленная по своему составу - содержит 4278 образцов, из них 2178 образцов яровой пшеницы. Ежегодно коллекция пополняется новыми поступлениями образцов из генных банков мира, отечественных и зарубежных научно-исследовательских учреждений.

Семенная коллекция генетических ресурсов пшеницы яровой (Triticum L.) включает 18 видов (T. aestivum L., T. durum Desf., T. turgidum L., T. spelta L., T. sphaerococcum Percival, T. compactum Host, T. aethiopicum Jakubz., T. carthlicum Nevski, T. ispahanicum Heslot, T. araraticum Jakubz., T. dicoccoides (Körn. ex Asch. \& Graebn.) Schweinf., T. dicoccum Schrank, T. monococcum L., T. polonicum L., T. turanicum Jakubz., T. timopheevii Zhuk., T. militinae Zhuk.et Migusch., T. Sinskajae,), различающихся по степени окультуривания, уровню плоидности и геномному составу, некоторые из видов имеют большое число ботанических разновидностей. Коллекция включает в себя дикие виды, разновидности, формы и культивируемые сорта из 73 стран мира. Преобладающее большинство образцов пшеницы в коллекции по своему происхождению из Европейских стран. Особое внимание уделяется сохранению отечественного генофонда яровой пшеницы, 19 \% образцов в коллекции белорусского происхождения. В коллекционном питомнике пшеницы яровой ежегодно изучается 500-600 образцов, представленных разными агроэкотипами.

Коллекция пшеницы наряду с другими коллекциями Национального банка семян генетических ресурсов хозяйственно полезных растений РУП «Научно-практический центр НАН Беларуси по земледелию» включена в Государственный реестр научных объектов, которые составляют национальное достояние Республики Беларусь (постановление Совета Министров Республики Беларусь от 27.12.2019 г. № 924).

Исследования по изучению коллекционного материала пшеницы яровой (Triticum L.) проводили в 2017-2019 гг. на опытном поле РУП «Научнопрактический центр НАН Беларуси по земледелию». Было изучено 645 образцов яровой пшеницы различного эколого-географического происхождения более чем из 40 стран мира. Образцы для изучения поступили в коллекцию из международных генных банков.

Почва опытных участков дерново-подзолистая легкосуглинистая, характеризуется следующими агрохимическими показателями пахотного слоя: $\mathrm{pH}-5,6-6,1$; содержание подвижного $\mathrm{P}_{2} \mathrm{O}_{5}-175-185$ мг/кг почвы и $\mathrm{K}_{2} \mathrm{O}-$ 230-260 мг/кг. Предшественник - гречиха.

Закладка коллекционного питомника осуществлялась согласно общепринятой методике [3]. Обработка почвы, посев и уход за посевами осуществлялись в соответствии с агротехникой, принятой для возделывания яровой мягкой пшеницы в Беларуси. Фенологические наблюдения и морфологические описания проводились по общепринятым методикам [4]. 
По результатам 3-х летнего изучения коллекции яровой мягкой пшеницы выделены следующие источники хозяйственно ценных признаков: короткостебельности - Yumai 34 (CHN), SW Kronjet (SWE), Mane Nick (ESP), CHRISMAR (FRA), Бухус 10 (IRQ); устойчивости к полеганию Воронежская 20, Экада 109, Набат (Россия), ВАJКА (Польша), Ротре (Швеция), FLAMBAR (Франция), KE HAN 9 и KENBEI-2 (Китай); устойчивости к мучнистой росе - FURIO (Франция), Sparrow (Великобритания), BAJKA (Польша), Pasteur (Нидерланды), Banks (Австралия); скороспелости Tanori F 71 (Мексика), PROSPER (Франция), NORIN 42 (Япония); озерненности колоса - ALFA (Польша), ECHO, BEHERT (Франция), SOPU (Финляндия), Абаа 95 (Ирак), SNØGG II (Норвегия), Corso (Германия), Sv.59433, BATALJ (Швеция); продуктивности колоса - BATALJ, Pompe (Швеция), Рима, Сибаковская Юбилейная (Россия), ALFA (Польша), Janus (германия), Lin Hong 14 (Китай); массы 1000 зерен - Juchi F2000 (Мексика), Подмосковная 10, Экада 109, Сибаковская Юбилейная (Россия), NING CHUN 12, Ken Da 3, YOU YI MAI (Китай), Злата (Украина), Бухус 10, Ашур (Ирак), Јanus (Германия), PRONTO (Франция); урожсайности - Janus (Германия), KE HAN NO.8 (Китай), SKIRNE (Норвегия), Дубравка (Россия); высокобелковости - Тулунская 50 (RUS), Long Fu 8 (CHN), Miana (FRA), Thasos (DEU), Подмосковная 10 (RUS); по комплексу хозяйственно ценных признаков Pompe (Швеция), BAJKA (Польша), BATALJ (Швеция), Janus (Германия), Бухус 10 (IRQ).

За последние 60 лет в Беларуси создано более 20 сортов мягкой яровой пшеницы, включенных в Государственный реестр: Минская, Белорусская 12, Белорусская 80, Виза, Ростань, Дарья, Рассвет, Тома, Сабина, Василиса, Ласка, Любава, Сударыня, Славянка, Монета, Мадонна, Награда, Эврика, Ладья, Каменка, из них 17 сортов за период с 1993 по 2019 гг. Сорта Сударыня, Ладья и Каменка созданы совместно с ФГБНУ «Верхневолжский ФАНЦ» на основе принципа организации экологической селекции. Сорт Дарья входит в число топ-10 наиболее распространенных сортов в Российской Федерации.

Сорта отечественной селекции служат основой комплекса адаптированных к условиям Беларуси хозяйственно-полезных признаков в перспективных программах селекционных работ, в частности: Виза - устойчивости к полеганию, поражению мучнистой росой и септориозом, высокого содержания белка и клейковины; Ростань - устойчивости к поражению мучнистой росой, септориозом и бурой ржавчиной, высокого содержания белка и клейковины; Дарья - высокой продуктивности, устойчивости к полеганию, поражению мучнистой росой, высокого содержания белка и клейковины; Рассвет - устойчивости к полеганию, поражению мучнистой росой, бурой ржавчиной и септориозом, носитель идентифицированных генов устойчивости Pm3d, Pm4b, высокого содержания белка и клейковины; Белорусская 80 
- носитель идентифицированных генов устойчивости pm1, pm2, pm3, pm4, pm5, pm6, pm8, pm16, pm17, pm18, pm19, pm21, pm22, pm23, pm24; Тома высокой продуктивности, устойчивости к полеганию, поражению мучнистой росой и септориозом; Сабина - устойчивости к поражению мучнистой росой и бурой ржавчиной, высокого содержания белка и клейковины; Василиса - устойчивости к мучнистой росе, крупносемянности; Ласка - устойчивости к мучнистой росе; Любава - устойчивости к мучнистой росе, септориозу, высокого качества зерна; Сударыня - устойчивости к мучнистой росе и бурой ржавчине, полеганию, по качеству зерна отнесен к ценным пшеницам; Славянка - ценный по качеству, обладает полевой устойчивостью к мучнистой росе; Монета - среднеранний, крупнозерный, продовольственного использования, устойчив к мучнистой росе; Мадонна - обладает полевой устойчивостью к мучнистой росе, сорт продовольственного использования, крупнозерный; Награда - устойчивый к полеганию, обладает полевой устойчивостью к мучнистой росе, крупнозерный; Эврика - высокоустойчив к мучнистой росе, слабовосприимчив к бурой ржавчине, септориозу и фузариозу колоса, с хорошими хлебопекарными качествами.

Таким образом, коллекция яровой пшеницы, объединившая в себя многообразие местных и селекционных сортов, является первоисточником селекционно ценных признаков для создания новых конкурентоспособных, высокоурожайных сортов. Созданные на этой основе сорта белорусской селекции в свою очередь служат источниками комплекса адаптированных к местным условиям хозяйственно-ценных признаков для дальнейшего повышения потенциала продуктивности, адаптивности и качества зерна мягкой яровой пшеницы в Беларуси.

\section{Список литературы}

1. Вавилов Н.И. Селекция как наука // Теоретические основы селекции. М.: Наука, 1987. С. 7-59.

2. Гриб С.И. Факторы прогресса в селекции яровой пшеницы в Беларуси / С.И. Гриб, Л.В. Кучинская // Проблемы и пути повышения эффективности растениеводства в Беларуси: Мат. межд. науч.-практ. конф. посвящ. 80-летию образования Института земледелия. 29 июня 2007 г. Жодино-Минск, 2007. С. 50-53.

3. Доспехов Б.А. Методика полевого опыта (с основами статистической обработки результатов исследований) / Б.А. Доспехов. - М.: Агропромиздат, 1985. - 351 с.

4. Унифицированный классификатор пшеницы Triticum L. / Ф.И. Привалов, С.И. Гриб, И.С. Матыс, [и др.] / РУП «Научно-практический центр НАН Беларуси по земледелию». - Минск, 2012. - 57c. 